\title{
PENGETAHUAN DAN KETERAMPILAN NELAYAN TENTANG KESELAMATAN KERJA DI PPP MUNCAR, BANYUWANGI
}

\author{
The Knowledge and Fishermen's Skill on Safety Works in PPP Muncar, Banyuwangi, East Java
}

Oleh:

Mohammad Imron ${ }^{2}$, Riris Nurkayah ${ }^{1}$, Fis Purwangka ${ }^{2 *}$

${ }^{1}$ Almuni Program Sarjana Departemen PSP FPIK IPB

${ }^{2}$ Departemen PSP FPIK IPB

*Korespondensi: fis@psp-ipb.org

\begin{abstract}
ABSTRAK
Pekerjaan pada kapal penangkap ikan merupakan pekerjaan yang tergolong membahayakan sehingga rawan menimbulkan kecelakaan kerja. Penyebab kecelakaan pada kapal perikanan, yaitu rendahnya kesadaran awak kapal tentang keselamatan kerja pada pelayaran dan kegiatan penangkapan, rendahnya penguasaan kompetensi keselamatan pelayaran dan penangkapan ikan, kapal tidak dilengkapi peralatan keselamatan sebagaimana seharusnya. Cuaca buruk seperti gelombang besar serta kurangnya pengetahuan dan keterampilan dalam penggunaan peralatan keselamatan kerja. Data yang dikumpulkan ada dua jenis, yaitu data primer dan data sekunder. Data primer diperoleh dengan cara wawancara mendalam melalui kuesioner. Sedangkan data sekunder diperoleh dengan cara melakukan penelusuran dokumen terkait informasi mengenai pengetahuan dan keterampilan nelayan. Pengambilan data dilakukan dengan metode purposive sampling terhadap beberapa pihak yang berkepentingan dengan keselamatan kerja nelayan. Penelitian ini bertujuan untuk mengidentifikasi pengetahuan dan keterampilan nelayan tentang keselamatan kerja. Hasil penelitian ini menunjukkan bahwa nelayan memiliki pengetahuan dan keterampilan yang minim mengenai keselamatan kerja dan prosedur bekerja di kapal serta pengelolaan keselamatan kerja di PPP Muncar tidak terlaksana dengan baik.
\end{abstract}

Kata kunci: keselamatan kerja, pengetahuan dan keterampilan nelayan, PPP Muncar

\begin{abstract}
Work at fishing vessel was dangerous, so prone to work accident. The cause of accident on fishing boats was the low awareness of the crew about safety work in shipping and activities arrest, the low mastery competence of shipping safety and fishing, a ship not furnished safety equipment as it should be. The data collected were two types, the primary and secondary data. The primary data was obtained by means of interviews through the questionnaire. Secondary data was obtained by means of documents related to know information about knowledge and fishermen's skill. The data was undertaken by purposive sampling method of several interested parties with occupational safety fishermen. The purpose of research was identifying knowledge and fishermen's skill on occupational safety. The results of this study indicate that fishermen had been minimal knowledge and skills concerning safety and work procedures on the boats as well as the management of occupational safety in Muncar fishing port has not performing well.
\end{abstract}

Keywords: safety works, knowledge and fishermen's skill, PPP Muncar 


\section{PENDAHULUAN}

\section{Latar Belakang}

Kabupaten Banyuwangi merupakan kabupaten paling ujung timur Propinsi Jawa Timur yang memiliki luas wilayah $5.782,50 \mathrm{~km}^{2}$ dengan panjang garis pantai $291,5 \mathrm{~km}$. Kabupaten Banyuwangi menyimpan potensi sumber daya pesisir yang cukup besar dan beragam. Hal tersebut mengindikasikan bahwa kabupaten Banyuwangi memiliki potensi pesisir yang besar khususnya potensi perikanan (RTRW Kabupaten Banyuwangi 2005 - 2015).

Kabupaten Banyuwangi mempunyai beberapa pelabuhan perikanan di kecamatannya. Salah satu pelabuhan perikanan di Kabupaten Banyuwangi adalah Pelabuhan Perikanan Pantai (PPP) Muncar yang memiliki daerah penangkapan ikan yang relatif dekat, yaitu diperairan sekitar Banyuwangi. Perairan Banyuwangi masih memiliki peluang potensi perikanan yang amat besar untuk dioptimalkan. Peluang ini terlihat dari peningkatan hasil tangkapan dari beberapa tahun terakhir. Pada tahun 2012 perairan Banyuwangi telah berkontribusi sebesar 44.469.348 kg dengan nilai $\mathrm{Rp}$ 406.031.616.605, lalu pada tahun 2013 naik menjadi $49.551 .442 \mathrm{~kg}$ dengan nilai $\mathrm{Rp}$ 658.183.025.200 (DKP Banyuwangi 2013). Menurut Komisi Nasional Pengkajian Stok Sumber Daya Ikan Laut atau KNPSSDIL, perairan Banyuwangi termasuk di dalam sebagian wilayah pengelolaan perikanan (WPP) Samudera Hindia yang meliputi perairan selatan Jawa dan Selat Bali. Daerah penangkapan nelayan Muncar berada di Perairan Selat Bali yang berhubungan langsung dengan Samudera Hindia yang potensi sumber daya ikannya masih dapat dimanfaatkan dan berkualitas ekspor.

Muncar merupakan daerah yang mempunyai produksi perikanan terbesar di daerah Banyuwangi, yang lebih dari 90\% seluruh produksi perikanan Banyuwangi didaratkan di Muncar (Rasyid, 2008). Oleh karena itu banyak masyarakat yang berada di Muncar bekerja di sektor perikanan salah satunya adalah sebagai nelayan. Pada tahun 2014 penduduk di Muncar yang berprofesi sebagai nelayan sebanyak 13.177 orang dari jumlah penduduk 124.651 orang (UPT Muncar).

Pekerjaan pada kapal penangkap ikan merupakan pekerjaan yang tergolong membahayakan dibanding pekerjaan lain, maka profesi pelaut kapal penangkap ikan memiliki karakteristik pekerjaan "3d" yaitu: membahayakan(dangerous), kotor (dirty) dan sulit (difficult) (FAO, 2000), dengan ketiga sifat pekerjaan tersebut ditambah faktor ukuran kapal yang didominasi kapal-kapal berukuran relatif kecil, berlayar pada perairan gelombang tinggi dengan kondisi cuaca tidak menentu sehingga dapat meningkatkan tingkat kecelakaan kapal penangkap ikan.

Keselamatan kapal penangkap ikan merupakan interaksi faktor-faktor yang kompleks, yakni human factor (nakhoda dan anak buah kapal), machines (kapal dan peralatan keselamatan) dan enviromental (cuaca dan skim pengelolaan sumberdaya perikanan). Permasalahan keelamatan atau kecelakaan akan timbul apabila salah satu elemen dari human factor, machines atau enviromental factor tersebut tidak berfungsi (Lincoln, 2002).

Menurut IMO (International Maritime Organization), besarnya persentase penyebab terjadinya kecelakaan kapal ikan menurut faktor kesalahan manusia sebesar 43,06\%, faktor alam 33,57\%, dan faktor teknis 23,35\%.

Penyebab kecelakaan pada kapal perikanan, yaitu rendahnya kesadaran awak kapal tentang keselamatan kerja pada pelayaran dan kegiatan penangkapan, rendahnya penguasaan kompetensi keselamatan pelayaran dan penangkapan ikan, kapal tidak dilengkapi peralatan keselamatan sebagaimana seharusnya, cuaca buruk seperti gelombang besar dan menderita sakit keras dalam pelayaran (Suwardjo et al. 2010). Oleh karena itu pengetahuan dan keterampilan dari awak kapal serta peralatan keselamatan dan kelayakan dari kapal seharusnya menjadi perhatian bagi awak kapal perikanan. Pengetahuan dan keterampilan tentang keselamatan kerja dari awak kapal dapat memperkecil resiko kecelakaan dini maupun kecelakaan yang telah terjadi, sehingga dapat 
terhindar dari akibat fatal yang tidak diinginkan. Tujuan dari penelitian ini adalah :

1. Mengidentifikasi keterkaitan Standar Kompetensi Kerja Nasional Indonesia (SKKNI) golongan penangkapan ikan dengan kurikulum sekolah kejuruan bidang penangkapan ikan;

2. Mengidentifikasi pengetahuan dan keterampilan nelayan tentang keselamatan kerja di PPP Muncar banyuwangi.

\section{Penelitian Terdahulu}

Penelitian mengenai pengetahuan dan keterampilan nelayan tentang keselamatan kerja telah dilakukan oleh beberapa peneliti salah satunya Amin (2015). Penelitian yang dilakukan di PPN Karangantu pada bulan September 2014 mengemukakakan bahwa kompetensi yang dimiliki oleh nelayan terbilang cukup rendah karena nelayan hanya menguasai $35,75 \%$ kompetensi yang seharusnya dimiliki oleh nelayan. Minimnya kompetensi yang dimiliki nelayan dapat berdampak langsung terhadap pengetahuan dan keterampilan yang dimiliki oleh nelayan. Hal yang perlu diperhatikan adalah, belum terlaksana dengan baik penerapan prosedur keselamatan kerja di PPN Karangantu karena kurangnya kesadaran dari pihak instansi terkait dan nelayan.

\section{METODE}

\section{Waktu dan Tempat Penelitian}

Penelitian dan pengambilan data dilakukan pada 30 November - 10 Desember 2015. Lokasi penelitian dilakukan di PPP Muncar Kabupaten Banyuwangi Provinsi Jawa Timur. Proses pengolahan dan analisis data dilakukan di Laboratorium Keselamatan Kerja dan Observasi Bawah Air, Departemen Pemanfaatan Sumberdaya Perikanan, Fakultas Perikanan dan Ilmu Kelautan Institut Pertanian Bogor.

\section{Metode Pengumpulan Data}

Metode penelitian ini menggunakan metode purposive sampling. Purposive sampling adalah teknik pengambilan sampel sumber data dengan pertimbangan tertentu yakni sumber data paling tahu tentang apa yang diharapkan, sehingga mempermudah peneliti menjelajahi objek atau situasi yang sedang diteliti (Sugiono 2010). Penggunaan metode purposive sampling dilihat berdasarkan karakteristik responden. Nelayan pada umumnya memiliki tingkat pengetahuan yang

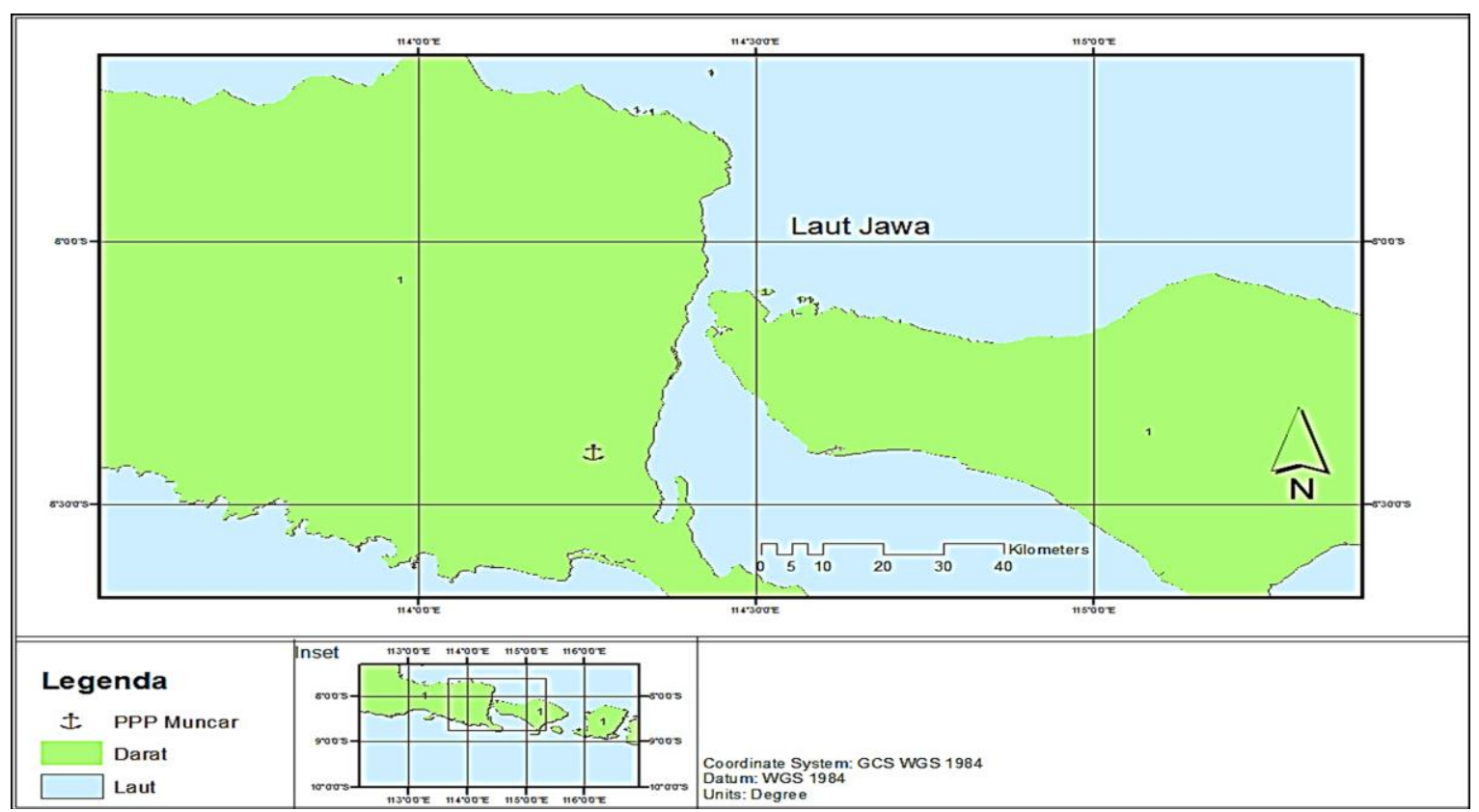

Gambar 1 peta lokasi penelitian 
sama megenai keselamatan kerja, karena mereka lebih mengandalkan pengalaman turun temurun di bandingkan panduan yang seharusnya. Tingkat pengetahuan yang cenderung sama tersebut akan menghasilkan jawaban yang cenderung seragam. Oleh karena itu menurut penulis dengan mewawancara beberapa nelayan dianggap sudah mewakili. Penulis memutuskan untuk mewawancarai 50 responden. Data yang dikumpulkan terdiri atas data primer dan data sekunder. Data primer diperoleh dengan cara wawancara mendalam terhadap pihak terkait kompetensi yang dimiliki oleh nelayan, seperti pengisi, penguras, $\mathrm{ABK}$, dan instansi yang berhubungan dengan kegiatan seperti pihak Unit Pelaksana Teknis Pelabuhan Perikanan Pantai (UPTPPP). Data sekunder dikumpulkan dengan cara melakukan penelusuran dokumen mengenai informasi tentang pengetahuan dan keterampilan nelayan terhadap instansi terkait dengan kurikulum atau materi pengetahuan dan keterampilan untuk nelayan.

\section{Prosedur Analisis Data}

Data yang diperoleh kemudian dianalisis untuk mendapatkan suatu kesimpulan. Bentuk teknik analisis data sebagai berikut:

\section{Analisis deskriptif komparatif}

Metode analisis deskriptif komparatif merupakan suatu metode yang digunakan dalam mengumpulkan, menyusun, menggunakan, serta menafsirkan data yang ada. Selanjutnya, data tersebut akan diuraikan secara lengkap, teratur, dan teliti terhadap suatu objek penelitian yang kemudian akan dibandingkan dengan data yang memiliki kesamaan terhadap suatu objek penelitian. Data yang di bandingkan adalah Standar Kompetensi Kerja Nasional Indonesia (SKKNI), kurikulum SMK Perikanan, dan kompetensi nelayan di PPP Muncar.

\section{Content Analisys atau analisis isi}

Analisis yang digunakan dalam penelitian ini adalah metode analisis dimana data deskriptif hanya di analisis menurut isinya. Metode content analisys, dilakukan dengan cara mengkaji secara mendalam mengenai isi atau materi yang terdapat pada dokumen (peraturan) mengenai kualitas sumberdaya khususnya nelayan. Kemudian dilakukan analisis numerik dengan cara melakukan perhitungan terhadap data yang diperoleh. Data yang diperoleh dibagi dalam beberapa kriteria dan di beri skor yang selanjutnya disajikan dalam bentuk persentase. Adapun kriteria untuk pemenuhan kompetensi menggunakan skoring yaitu:

Tabel 1 Kriteria pemenuhan standar kompetensi

\begin{tabular}{lc}
\hline $\begin{array}{l}\text { Kriteria pemenuhan standar } \\
\text { kompetensi }\end{array}$ & Skor \\
\hline Dipenuhi & 4 \\
\hline Dipenuhi sebagian & 0 \\
\hline Tidak dipenuhi & Persentase kompetensi (\%) \\
\hline - $\quad$ Pemenuhan kompetensi & X 100\% \\
\hline Relemen kompetensi & Rata-rata persentase kompeensi (\%) = \\
$\frac{\sum \text { persentase kompetensi }}{\sum \text { standar kompetensi }}$ X 100\%
\end{tabular}

\section{HASIL DAN PEMBAHASAN}

\section{Armada Penangkapan Ikan}

Armada penangkapan ikan merupakan salah satu faktor yang mendukung keberhasilan dalam suatu operasi penangkapan. Armada penangkapan ikan yang digunakan berupa kapal perikanan, yang didefinisikan sebagai kapal, perahu, atau alat apung lainnya yang digunakan untuk melakukan penangkapan ikan, mendukung operasi penangkapan ikan, pembudidayaan ikan, pengangkutan ikan, pengolahan ikan, pelatihan perikanan, dan penelitian/eksplorasi perikanan (Undang-Undang RI No.45 Tahun 2009). Pada Tabel 2 dapat dilihat jumlah armada penangkapan ikan di PPP Muncar tahun 2010-2014.

Tabel 2 menunjukkan jumlah armada penangkapan yang ada di PPP Muncar dari tahun 2010-2014. Selama periode 2010-2014 jumlah armada penangkapan ikan di PPP Muncar mengalami fluktuasi. Faktor yang 
Tabel 2 Jumlah armada penangkapan ikan di PPP Muncar Banyuwangi tahun 2010-2014

\begin{tabular}{lllllll}
\hline Tahun & $\begin{array}{l}\text { Kapal Motor } \\
\text { 5 GT }\end{array}$ & $\begin{array}{l}\text { Kapal Motor } \\
\text { 5-10 GT }\end{array}$ & $\begin{array}{l}\text { Kapal Motor } \\
\text { 10-30 GT }\end{array}$ & $\begin{array}{l}\text { Kapal Motor } \\
\text { Tempel }\end{array}$ & $\begin{array}{l}\text { Perahu } \\
\text { Tanpa Kapal }\end{array}$ & Total \\
\hline 2010 & 566 & 319 & 189 & 676 & 121 & 1871 \\
2011 & 566 & 322 & 189 & 686 & 111 & 1874 \\
2012 & 548 & 315 & 205 & 680 & 118 & 1866 \\
2013 & 548 & 319 & 189 & 671 & 108 & 1835 \\
2014 & 553 & 229 & 197 & 656 & 78 & 1783 \\
\hline
\end{tabular}

Sumber: Laporan tahunan PPP Muncar

mempengaruhinya adalah bertambahnya sumberdaya manusia yang bekerja sebagai nelayan.Tahun 2010 terdapat 566 unit kapal motor 5 GT, 319 unit kapal motor 5-10 GT, 189 unit kapal motor 10-30 GT. Selanjutnya pada tahun 2011 tidak ada perubahan jumlah pada kapal motor 5 GT yaitu 566 unit, kemudian terjadi kenaikan jumlah kapal motor 5 -10 GT menjadi 322 unit, dan tidak ada perubahan pada kapal motor 10-30 GT. Namun pada tahun 2012 mengalami penurunan pada kapal motor 5 GT menjadi 548 unit, kapal motor 5-10 GT menjadi 315 unit, sedangkan kapal motor 1030 GT mengalami kenaikan menjadi 205 unit. Pada tahun 2013 tidak ada perubahan pada kapal motor 5 GT, namun terjadi kenaikan kembali pada kapal motor 5-10 GT menjadi 319 unit dan terjadi penurunan pada kapal motor 10-30 GT menjadi 189 unit. Pada kapal motor tempel selalu terjadi perubahan jumlah yaitu

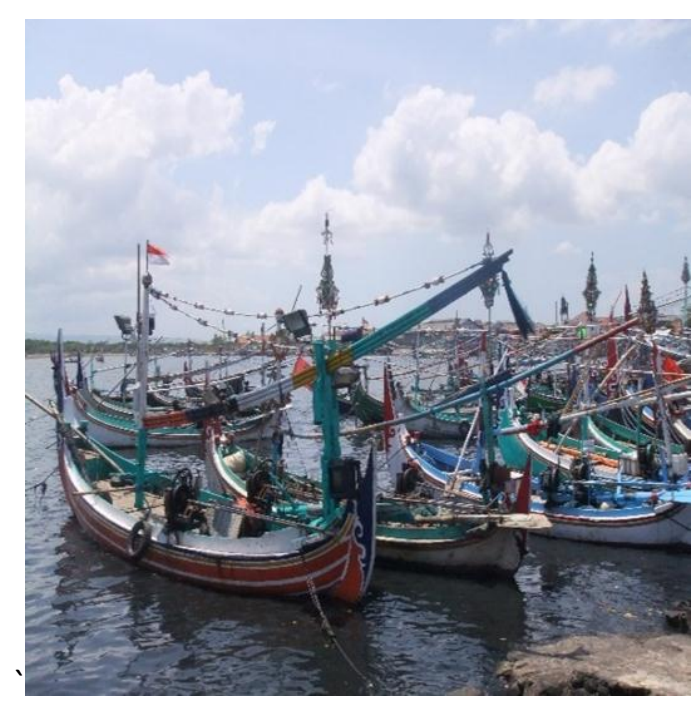

tahun 2010 terdapat 676 unit, tahun 2011 terdapat 686 unit, tahun 2012 terdapat 680 unit, dan 2013 terdapat 671 unit. Periode 20102014 jumlah perahu tanpa motor juga mengalami perubahan yaitu tahun 2010 terdapat 121 unit, 2011 terdapat 111 unit, 2012 terdapat 118 unit, dan 2013 terdapat 108 unit. Fluktuasi yang terjadi pada jumlah armada kapal penangkapan ikan tidak signifikan sehingga jumlah kapal di PPP Muncar dapat dikatakan stagnan.

\section{Alat Penangkapan Ikan}

Alat penangkap ikan adalah sarana dan perlengkapan atau benda-benda lainnya yang dipergunakan untuk menangkap ikan. Alat penangkap ikan mempunyai peranan penting dalam berbagai macam aspek, karena dengan adanya alat penangkap ikan yang diperankan nelayan di seluruh dunia. Aspek

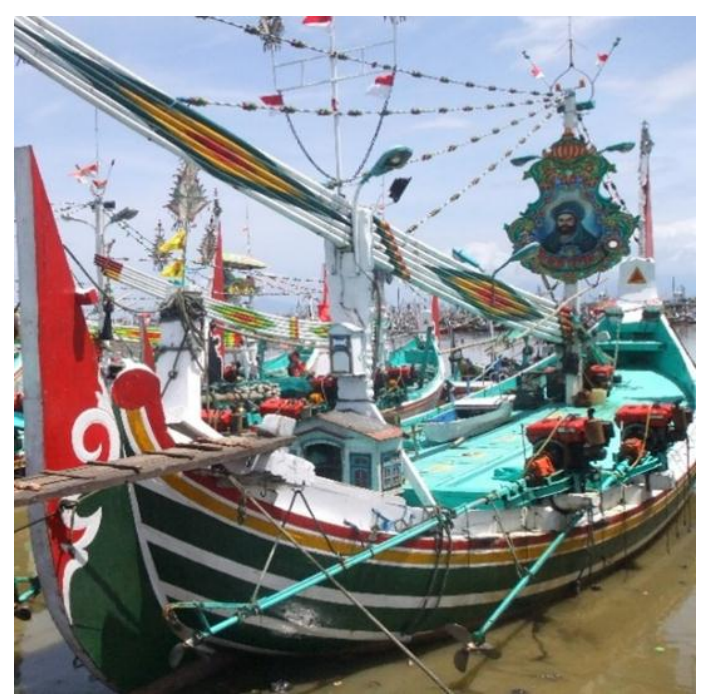

Gambar 2 Kapal nelayan di PPP Muncar 
Tabel 3 Jumlah alat penangkapan ikan di PPP Muncar Banyuwangi tahun 2010-2014

\begin{tabular}{llllllll}
\hline Tahun & Purse Seine & Payang & Gill Net & Lift Net & $\begin{array}{l}\text { Hook and } \\
\text { Line }\end{array}$ & Traps & Total \\
\hline 2010 & 203 & 42 & 679 & 276 & 642 & 309 & 2151 \\
2011 & 203 & 42 & 682 & 276 & 645 & 282 & 2130 \\
2012 & 207 & 42 & 679 & 276 & 642 & 282 & 2128 \\
2013 & 203 & 62 & 674 & 280 & 657 & 287 & 2163 \\
2014 & 190 & 62 & 624 & 280 & 655 & 280 & 2091 \\
\hline
\end{tabular}

Sumber: Laporan tahunan PPP Muncar

ketenagakerjaan, aspek ekonomi, aspek perdagangan atau komersial, aspek sosial dan organisasi, aspek pertahanan dan keamanan negara, dan aspek kesehatan yang dapat hidup dan berkembang. Pada Tabel 2 dapat dilihat data jumlah alat penangkapan ikan di PPP Muncar tahun 2010-2014.

Berdasarkan Tabel 3, dapat dilihat jenis alat penangkapan ikan yang terdapat di PPP Muncar. Selama periode 2010-2014 fluktuasi yang terjadi pada alat penangkapan ikan tidak signifikan. Fluktuasi yan terjadi pada alat penangkapan ikan di PPP Muncar ini disebabkan oleh beberapa faktor, yaitu adanya pergantian penggunaan alat tangkap satu ke alat tangkap lainnya, karena rata-rata nelayan di PPP Muncar tidak hanya mempunyai satu alat tangkap. Nelayan akan melakukan pergantian penggunaan alat tangkap sesuai kondisi potensi sumberdaya ikan. Faktor lainnya yaitu adanya kerusakan pada alat tangkap dan nelayan tidak memiliki modal yang cukup untuk mengoperasikan alat tangkap.

\section{Kompetensi Nelayan SKKNI (Standar Kompetensi Kerja Nasional Indonesia)}

Penduduk yang bermukim di sekitar PPP Muncar, Banyuwangi sebagian besar berprofesi sebagai nelayan. Nelayan yang berada di lokasi tersebut umumnya melakukan operasi penangkapan ikan secara manual dengan tenaga manusia. Nelayan di PPP Muncar dibagi menjadi dua kategori yaitu nelayan buruh dan nelayan pemilik.
Alat tangkap yang digunakan oleh nelayan setempat yaitu diantaranya gillnet (jaring insang) dengan nama daerah setet, lift net (jaring angkat) dan purse seine (pukat cincin) dengan nama daerah slerek. Nelayan setempat biasanya melakukan operasi penangkapan ikan di daerah sekitar Teluk Sembulungan dan di Selat Bali. Adapun tabel identitas nelayan dari 50 responden yang ada di PPP Muncar.

Berdasarkan data pada tabel diatas, didapatkan bahwa nelayan di PPP Muncar, Banyuwangi hanya menguasai 33,31\% dari elemen kompetensi yang seharusnya dimiliki oleh nelayan, sedangkan $66,69 \%$ elemen kompetensi yang lainnya nelayan belum menguasainya. Faktor penyebab kurangnya pemahaman nelayan di PPP Muncar banyuwangi terkait dengan standar kompetensi yang seharusnya dimiliki nelayan antara lain minimnya kesadaran nelayan akan pentingnya kompetensi, nelayan belum memiliki sertifikat kompetensi, serta belum adanya bentuk sosialisasi maupun pelatihan terkait dengan standar kompetensi nelayan yang diadakan di lokasi tersebut. Selain itu masih kurangnya nelayan yang memiliki pendidikan dibidang perikanan, karena pendidikan di bidang perikanan dapat diperoleh disekolah khususnya sekolah menengah kejuruan yang memiliki kurikulum khusus yang sesuai bidangnya. 
Tabel 4 Identitas nelayan di PPP Muncar, Banyuwangi

\begin{tabular}{|c|c|c|c|}
\hline No & Kriteria & Jumlah & Persentase \\
\hline \multirow[t]{5}{*}{1} & Kapal & & \\
\hline & $<5 \mathrm{GT}$ & 30 & $60 \%$ \\
\hline & 5-10GT & - & - \\
\hline & $10-30 \mathrm{GT}$ & 20 & $40 \%$ \\
\hline & $>30 \mathrm{GT}$ & - & - \\
\hline \multirow[t]{4}{*}{2} & Pendidikan & & \\
\hline & SD & 37 & $74 \%$ \\
\hline & SMP & 8 & $16 \%$ \\
\hline & SMA/SMK & 5 & $10 \%$ \\
\hline \multirow[t]{4}{*}{3} & Usia (tahun) & & \\
\hline & $18-30$ & 10 & $20 \%$ \\
\hline & $31-40$ & 20 & $40 \%$ \\
\hline & $41-60$ & 20 & $40 \%$ \\
\hline \multirow[t]{4}{*}{4} & Masa kerja ( & hun) & \\
\hline & $5-10$ & 20 & $40 \%$ \\
\hline & $11-20$ & 17 & $34 \%$ \\
\hline & $21-30$ & 13 & $26 \%$ \\
\hline
\end{tabular}

Sumber: Hasil wawancara dengan nelayan di PPP Muncar

\section{PEMBAHASAN UMUM}

Kebijakan pengaturan keselamatan kapal penangkap ikan pada dasarnya adalah kebijakan kelaikan kapal dan pengawakan kapal penangkap ikan. Kapal penangkap ikan harus memenuhi kelaiklautan dan laik operasi penangkapan. Laiklaut meliputi laik kapal dan laik pengawakan kapal sementara laik operasi penangkapan meliputi laik alat tangkap, daerah penangkapan dan penanganan hasil tangkap. Salah satu kebijakan tersebut adalah Standar Kompetensi Kerja Nasional Indonesia (SKKNI) golongan penangkapan ikan yang digunakan sebagai acuan dalam pengembangan sumberdaya manusia di bidang penangkapan ikan. Selain itu SKKNI juga digunakan sebagai informasi untuk penegembangan program dan kurikulum dan sebagai acuan dalam penyelenggaraan pelatihan dan sertifikasi.

Namun keadaan di lapang yaitu di PPP Muncar belum sesuai dengan SKKNI karena masih banyak kapal penangkap ikan yang belum memenuhi kelaiklautan dan kelaikan operasi penangkapan ikan. Berdasarkan SKKNI terdapat 23 elemen kompetensi yang harus dikuasai oleh nelayan, namun hanya terdapat 9 jenis kompetensi yang dikuasai oleh nelayan di PPP Muncar, yaitu:

1. Merencanakan operasi penangkapan ikan 
Nelayan di PPP Muncar dalam merencanakan operasi penangkapan ikan hanya menguasai 50\% dari elemen kompetensi yang seharusnya dikuasai. Hal yang dilakukan oleh nelayan terkait merencanakan operasi penangkapan ikan yaitu menentukan alat penangkap ikan, daerah penangkapan ikan, dan jenis ikan sasaran dan melakukan estimasi waktu operasi penangkapan ikan, menghitung logistik operasional kapal dan logistik ABK.

\section{Menyiapkan kelaiklautan kapal}

Nelayan di PPP Muncar hanya menguasai 37,5\% dari elemen kompetensi yang seharusnya dikuasai. Adapun hal yang dilakukan oleh nelayan terkait menyiapkan kelaiklautan kapal yaitu melengkapi dokumen kapal, melengkapi jumlah awak kapal sesuai kualifikasi dan fungsinya, melengkapi perlengkapan keselamatan kapal dan manusia. Namun dari masing-masing elemen kompetensi tersebut nelayan hanya menguasai sebagian.

3. Menyiapkan kelaikan operasi penangkapan ikan

Nelayan di PPP Muncar menguasai 83,33\% dari elemen kompetensi yang seharusnya dikuasai. Adapun hal yang dilakukan nelayan terkait menyiapkan kelaikan operasi penangkapan ikan yaitu melengkapi dokumen perijinan yang terkait dengan usaha penangkapan ikan yang hanya dikuasai sebagian, melengkapi kebutuhan perbekalan kapal dan awak kapal, dan menyiapkan alat dan perlengkapan penangkap ikan.

\section{Melaksanakan tugas jaga laut}

Nelayan di PPP Muncar hanya menguasai 50\% dari elemen kompetensi yang seharusnya dikuasai. Adapun hal yang dilakukan oleh nelayan terkait melaksanakan tugas jaga laut yaitu memantau rute, pengendalian kapal dan keamanan berlayar.

\section{Merakit alat penangkap ikan}

Nelayan di PPP Muncar mengakui bahwa sepenuhnya dapat merakit alat tangkap sendiri. Alat tangkap yang biasa digunakan oleh nelayan yaitu (1) pukat cincin (slerek) cara yang dilakukan olh nelayan dalam merakit pukat cincin yaitu menyiapkan kebutuhan peralatan kerja dan bahan pukat cincin dan merangkai komponen pukat cincin (2) jaring insang, cara yang dilakukan dalam merakit jaring insang yaitu menyiapkan kebutuhan peralatan kerja dan bahan jaring insang dan merangkai komponen jaring insang

3. Mengoperasikan alat penangkap ikan

Nelayan di PPP Muncar menguasai 100 $\%$ elemen kompetensi dalam mengoperasikan alat penangkap ikan.

4. Melakukan perawatan alat penangkap ikan

Nelayan di PPP Muncar hanya menguasai 66,66\% dari elemen kompetensi yang seharusnya dikuasai dalam melakukan perawatan alat penangkap ikan. Jenis perawatan yang dilakukan oleh nelayan yaitu perawatan alat penangkap ikan yang menggunakan bahan webbing.

5. Melakukan perbaikan alat penangkap ikan

Nelayan di PPP Muncar hanya menguasai $78,57 \%$ dari elemen kompetensi yang seharusnya dikuasai dalam melakukan perbaikan alat penangkap ikan. Jenis perbaikan yang dilakukan oleh nelayan yaitu perbaikan alat penangkap ikan yang menggunakan bahan webbing.

6. Melakukan penanganan ikan diatas kapal

Nelayan di PPP Muncar hanya 83,33\% dari elemen kompetensi yang seharusnya dikuasai dalam melakukan penaganan ikan diatas kapal. Jenis penaganan yang dilakukan oleh nelayan yaitu penaganan ikan pelagis kecil.

Kapal-kapal di PPP Muncar merupakan kapal yang berukuran kecil. Kapal yang berukuran < 5 GT yaitu kapal setet dan bagan hanya terdiri dari 1 sampai 2 orang ABK. Sebelum melaut, persiapan yang dilakukan oleh nelayan yaitu menyiapkan bahan bakar, menyiapkan alat tangkap, menyiapkan kapal seperti pengecekan mesin. Kapal-kapal kecil 
rata-rata berukuran panjang 9-12 m. Pada kapal-kapal kecil tidak ada peralatan keselamatan standar, seperti life bouy, life jacket, GPS, dan lampu. Kondisi ini dapat membahayakan keselamatan nelayan, apabila terjadi kecelakaan atau keadaan darurat lainnya. Nelayan hanya mengandalkan peralatan alternatif yang ada di kapal seperti jerigen sebagai alat apung, dan nelayan biasanya mengantisipasinya dengan cara membawa telepon genggam untuk memberikan informasi jika terjadi sesuatu ketika melaut. Namun tidak semua nelayan melakukan hal tersebut.

Selain kapal yang berukuran < 5 GT terdapat pula kapal yang berukuran 10-30 GT yaitu kapal purse seine dengan nama daerah slerek. Kapal slerek yang ada di Muncar berukuran panjang $20 \mathrm{~m}-23 \mathrm{~m}$. Ketika melakukan penangkapan ikan, kapal slerek membawa ABK 50- 60 orang dengan 2 kapal, yaitu kapal yang membawa alat tangkap dan kapal yang mengangkut hasil tangkapan ( kapal pemburu). ABK yang ada di kapal alat tangkap $30-40$ orang sedangkan $15-20$ orang ada di kapal pemburu. Daerah penangkapan ikan pada kapal slerek yaitu disekitar selat bali yang ditempuh dengan 5-6 jam perjalanan dari pelabuhan. Nelayan slerek biasa berangkat melaut pada siang hari atau sore hari dan sampai di DPI pada malam hari.

Pada kapal slerek terdapat pembagian kerja, yaitu wilayah kerja darat dan laut. Untuk wilayah darat yaitu penguras dan pengisi sedangkan wilayah laut merupakan nelayan yang melakukan operasi penangkapan. Tugas dari penguras yaitu membersihkan kapal setelah melaut sedangkan tugas dari pengisi adalah melakukan persiapan alat tangkap, persiapan mesin, persiapan dan perbekalan kapal. Untuk wilayah kerja dilaut yaitu nahkoda (juragan), perwira (pengedar), dan ABK. Tugas nahkoda di kapal slerek adalah sebagai fishing master yaitu mencari daerah penangkapan ikan dan mengamati tanda- tanda adanya ikan. Sedangkan tugas pengedar adalah mengumpulkan ABK ketika kapal akan berangkat berlayar namun ketika melaut tugas dari pengedar sama dengan ABK lainnya. Tugas ABK terbagi menjadi berbagai jenis, yaitu juru mesin, juru kemudi, menjaga pelampung, menjaga tali, menurunkan jaring atau setting dan hauling dan lain-lain.

Pada kapal slerek juga tidak terdapat peralatan keselamatan kerja dan ketika melakukan operasi penangkapan ikan, tidak semua nelayan menggunakan perlengkapan keselamatan kerja. Perlengkapan keselamatan diri yang digunakan nelayan hanya sepatu dan tidak semua nelayan menggunakannya, karena nelayan sudah terbiasa dengan kondisi tersebut. Alat-alat bantu dan lampu navigasi juga tidak terdapat di atas kapal, apalagi radio komunikasi. Perlengkapan navigasi tersebut, selain berguna untuk menginformasikan posisi kepada kapal, menginformasikan pula jenis kegiatan yang sedang dilakukan. Penggunaan lampu-lampu dan peralatan navigasi tersebut merupakan bagian yang penting dalam keamanan dan keselamatan pelayaran.

Minimnya perlengkapan dan pemikiran mengenai alat keselamatan yang ada dan tidak sesuai dengan standar nasional untuk kapal berukuran panjang < $24 \mathrm{~m}$ pada kapal penangkapan ikan di PPP Muncar otomatis akan mempengaruhi risiko keselamatan nelayan yang sedang melakukan operasi penangkapan ikan di kapal tersebut ketika terjadi kecelakaan kapal di laut seperti pada saat kapal terbalik, tenggelam, terbawa arus, tabrakan, kebakaran serta kecelakaan kerja.

Hal tersebut dikarenakan (1) rendahnya pengetahuan dan keterampilan nelayan mengakibatkan rendahnya kesadaran terhadap pentingnya alat-alat keselamatan di kapal nelayan PPP Muncar (2) harga dari alat keselamatan yang relatif mahal, sehingga tidak semua nelayan mampu membelinya terutama untuk alat life buoy dan kompas (3) prioritas kebutuhan dari masing-masing alat keselamatan yang berbeda menurut nelayan, sehingga tidak semua alat keselamatan tersebut perlu dipenuhi.

Pada tingkat Internasional $\mathrm{IMO} / \mathrm{ILO} / \mathrm{FAO}$ telah mengatur standar keselamatan kapal yang berukuran $\geq 24 \mathrm{~m}$, sedangkan untuk pengaturan kapal-kapal berukuran < $24 \mathrm{~m}$ diberikan sepenuhnya kepada pemerintah setempat. Menurut data 
yang didapatkan, armada kapal perikanan berukuran kecil (panjang kapal < $24 \mathrm{~m}$ ) belum banyak diatur oleh pemerintah sementara jumlah kapal berukuran kecil mendominasi armada industri perikanan tangkap nasional, yakni mencapai 94\% dari total armada kapal penangkap ikan (DKP, 2009). Belum adanya peraturan khusus tentang keselamatan kapalkapal kecil menunjukan bahwa keselamatan nelayan dalam kegiatan penangkapan di Indonesia sampai saat ini belum diperhatikan dan belum ada kebijakan yang jelas dari pemerintah daerah dan pusat.

Minimnya pengelolaan pemerintah terkait keselamatan kerja nelayan terlihat di lapangan, tidak adanya sosialisasi serta pelatihan mengenai keselamatan kerja membuat kondisi sumber daya manusia (SDM) di lapangan memiliki pengetahuan yang sangat terbatas. Dalam UU No. 17 tahun 2008 tentang Pelayaran pasal 261-265 dijelaskan bahwa penyelenggaraan dan pengembangan sumber daya manusia di bidang pelayaran bertujuan agar tersedianya sumber daya manusia yang profesional, kompeten, disiplin, dan bertanggung jawab serta memenuhi standar nasional dan internasional. Didalamnya termasuk sumber daya manusia di bidang keselamatan dan keamanan pelayaran. Pendidikan yang dimaksud dapat ditempuh dengan jalur formal maupun informal serta merupakan tanggung jawab pemerintah daerah dalam memberikan layanan dan kemudahan serta menjamin terselenggaranya pendidikan dan pelatihan di bidang pelayaran yang bermutu bagi setiap warga negara tanpa diskriminasi.

\section{KESIMPULAN}

Kesimpulan yang diperoleh dari hasil penelitian ini adalah:

1. Kompetensi nelayan yang telah diatur dalam Standar Kompetensi Kerja Nasional Indonesia (SKKNI) dalam bidang penangkapan ikan yang diterbitkan oleh Keputusan Menteri Tenaga Kerja dan Tramnsmigrasi No 298 tahun 2013 belum sepenuhnya dikuasai oleh nelayan di PPP Muncar, Banyuwangi, hal tersebut karena nelayan hanya menguasai 33,31\% dari elemen kompetensi yang seharusnya dimiliki oleh nelayan, sedangkan $66,69 \%$ elemen kompetensi yang lainnya nelayan belum menguasainya.

2. Kurikulum pada Sekolah Menengah Kejuruan Perikanan sudah menunjang Standar Kompetensi Kerja Nasional Indonesia (SKKNI).

\section{DAFTAR PUSTAKA}

[DKP] Departemen Kelautan dan Perikanan dan [JICA] Japan International. Cooperation Agency. 2009. Indonesian Fisheries Statistics Index 2009.

[DKP Kabupaten Banyuwangi] Dinas Kelautan dan Perikanan Kabupaten Banyuwangi. 2014. Laporan Statistik Perikanan Tangkap dan Budidaya Kabupaten Banyuwngi. Banyuwangi (ID): DKP Kabupaten Banyuwangi.

Departemen Perhubungan, 2013. Peraturan Menteri Perhubungan Nomor 70 Tahun 2013 Tentang Pendidikan dan Pelatihan, Sertifikasi serta Dinas Jaga Laut. Peraturan Perundangan Bidang Transportasi. Jakarta (ID): Departemen Perhubungan.

Food and Agriculture Organization, 2000. The State of World Fisheries and Aquaculture. Part 2. Selected Issues Facing Fishers and aquaculturists. Rome, Italy.

[ILO] International Labour Organization. 2000. Safety and Health in the Fishing Industry. Safety and Health Issues in the Fishing Industry. Geneva. 
[IMO] International Maritime Organization. 2007. Formal Safety Assessment. Consolidated text of the Guidelines for Formal Safety Assessment (FSA) for use in the IMO rule-making rocess (MSC/Circ.1023-ME C/Circ.392), London (GB): Maritime Safety Committe.

Lincoln J. 2002. Vide Djodjo Suwardjo, 2010. Proceedings of the International Fishing Industry Safety and Health Conference. U.S. Department of Health and Human Services, Public Health Service, Center for Disease Control and Prevention, National Institute for Occupational Safety and Health, Occupational Health Program, Department of Environmental Health, Harvard School of Public Health. Massachusetts, U.S.A.

Pemerintah Republik Indonesia. 2003. Undang-Undang Nomor 13 tahun 2003 tentang Ketenagakerjaan. Jakarta (ID): Sekretariat Negara

Pemerintah Republik Indonesia. 2003. Undang-Undang Nomor 20 tahun 2003 tentang Sistem Pendidikan Nasional. Jakarta (ID): Sekretariat Negara

Pemerintah Republik Indonesia. 2008. Undang-Undang Republik Indonesia Nomor 17 Tahun 2008 tentang Pelayaran. Jakarta (ID): Sekretariat Negara.

Pemerintah Republik Indonesia. 2009. Undang-Undang Republik Indonesia Nomor 45 Tahun 2009 tentang Perikanan. Jakarta (ID): Sekretariat Negara

Pemerintah Republik Indonesia. 2013. Keputusan Menteri Tenaga Kerja dan Transmigrasi Nomor 298 tahun 2013 tentang Penetapan Standar Kompetensi Kerja Nasional Indonesia Kategori Pertanian, Kehutanan, dan Perikanan Golongan Pokok Perikanan Golongan Penangkapan Ikan Sub Golongan Penangkapan Ikan di Laut. Jakarta (ID): Sekretariat Negara

Rasyid A. 2008. Isolasi Asam Lemak Tak Jenuh Majemuk Omega-3 dari Ikan Lemuru (Sardinella sp). Di dalam: Prosiding Seminar Riptek Kelautan Nasional; Pusat Penelitian Oseanografi LIPI; 3 September 2008. Jakarta.http://www.barunajaya.com/dwld/docs/20080903924-MAK2-3.PDF [15 Januari 2016].

Sugiono. 2010. Memahami Penelitian Kualitatif. Bandung (ID): Alfabeta.

Suma'mur. 1989. Keselamatan Kerja dan Pencegahan Kecelakaan . Cetakan keempat. Jakarta : CV. Haji Mas Agung.

Suwardjo D, Haluan J, Indrajaya, Poernomo S H. 2010. Keselamatan Kapal Penangkap Ikan, Tinjauan dari Aspek Regulasi Nasional dan Internasional. Jurnal. Bogor : Institut Pertanian Bogor.

[UPT PPP Muncar] Unit Pelaksana Teknis Pelabuhan Perikanan Pantai Muncar. 2014. Laporan Tahunan Unit Pelaksana Teknis Pelabuhan Perikanan Pantai (PPP) Muncar. Banyuwangi: UPT PPP Muncar. 